\title{
THE RECONSTRUCTION METHOD OF HODAYOT MANUSCRIPTS
}

\author{
Philip Suciadi Chia' ${ }^{1)}$ Juanda ${ }^{2)}$ \\ 1) Southern Baptist Theological Seminary - Kentucky USA \\ E-mail:pchia275@students.sbts.edu \\ 2) Evangelical Theological Seminary of Indonesia - Surabaya \\ E-mail: juanda@sttii-surabaya.ac.id
}

\begin{abstract}
Hodayot, in Hebrew means thanksgiving Psalms, is a collection of approximately thirty poems that give thanks to God. Hodayot is an important resource for understanding the piety and religious devotion of those who composed and recited them.In reconstructing of the original scroll, uses direct joins method, vertical alignment of material, horizontal alignment of material, and placement of fragments according to the Scribal Hands. The benefits of this reconstruction: Firstly, the accurate placing of adjacent fragments has enabled more portions of meaningful text to be recovered. Secondly, this method allows the original length of the scroll to be estimated as twenty-seven or twenty-eight columns of forty-one to forty-two lines each. The average length of lines is also known. Thirdly, it is now possible to investigate the overall structure of the collection, particularly when the data from the Cave 4 manuscripts is also considered. This group contains all of the compositions identified as Teacher Hymns and it strengthens the argument that they represent a distinct group by a single author.
\end{abstract}

Keywords: Psalms, Hodayot, Manuscripts, Fragments

\section{INTRODUCTION}

Hodayot, in Hebrew means thanksgiving Psalms, is a collection of approximately thirty poems that give thanks to God. ${ }^{1}$ It was named Hodayot by Sukenik because of the distinctive opening phrase -

\footnotetext{
1 Sukenik designated this "The Thanksgiving Scroll", and the poems themselves came to be called "Hodayot" (in English, Thanksgiving Psalms or Thanksgiving Hymns). See Eleazar Sukenik, The Dead Sea Scrolls of the Hebrew University (Jerusalem: Magnes Press, Hebrew University, 1955).

2 Bonnie Pedrotti Kittel, The Hymns of Qumran(Translation and Commentary), ed.
}

I thank you, Lord or Blessed you, Lord with which some of the hymn-like compositions begin. ${ }^{2}$ Seven copies of the collection were found in the caves near Qumran, and this relatively large number indicates its importance. In addition, hodayot is an important resource for

Douglas A. Knight (Ann Arbor, Michigan: Edwards Brothers, Inc., 1981), 1; Julie A. Hughes, Scriptural Allusions and Exegesis in the Hodayot (Michigan: Brill, 2006), 2; Eileen M. Schuller and Carol A. Newsom, The Hodayot (Thanksgiving Psalms): A Study Edition of $1 Q H^{a}$ (Atlanta: Society of Biblical Literature, 2012), 1. See the similarities and dissimilarities for the example. 
understanding the piety and religious devotion of those who composed and recited them. ${ }^{3}$ These psalms reflect the distinctive vocabulary and religious ideas that marked the type of Judaism found in other primary works of the Qumran community such as the Rule of the Community and the War Scroll. ${ }^{4}$

\section{DISCOVERY 1QH}

The largest and the most complete copy, $1 \mathrm{QH}^{\mathrm{a}}$, is the scroll found by Taamira Bedouin in Cave 1 near Khirbet Qumran, and purchased in November 1947 by Eliezer Sukenik of the Hebrew University of Jerusalem. ${ }^{5}$ This is a very large scroll with forty-one or forty-two lines per page; the size, care in preparation, and beautiful calligraphy indicate that this was an important scroll that had some status in the community. 6 Two years later when archaeologists excavated Cave 1, archaeologists also found two more small pieces (fragments) that were very similar both in handwriting and in content that overlaps with the large scroll. ${ }^{7}$ These fragments were all that remained of a scroll designated $1 \mathrm{Q} 35 / 1 \mathrm{QH}^{\mathrm{b}}$, another copy of the same collection; they were published in

\footnotetext{
${ }^{3}$ For further explanation see the content' section of this paper. Emile Puech, "Hodayot" in Encyclopedia of the Dead Sea Scrolls, ed. Lawrence H. Schiffman and James C. VanderKam (Oxford: Oxford University Press, 2000), 368.

${ }^{4}$ This idea is to enter the Community is to enter into God's Covenant with the resolve to fortify oneself and to persevere (compare to the Rule of the Community and the Damascus Document). See Eileen Schuller, "Hodayot" in John J. Collins and Daniel C. Harlow, The Eerdmans of Dictionary Early Judaism (Grand Rapids, Michigan: William B. Eerdmans Publishing Company, 2010), 747.

5 Sukenik, The Dead Sea Scrolls, 2. Kittel, The Hymns of Qumran, 1. Some people, such as Schuller and Newsom, write his first name as Eleazar. See Schuller, "Hodayot", 747 and Schuller and Newsom, The Hodayot, 1.
}

1955 by J. T. Milik in DJD - Discoveries in the Judean Desert - $1 .^{8}$

\section{QH}

From the fragments founds in Cave 4, six more manuscripts were identified that contained text that overlapped with $1 \mathrm{QH}^{\mathrm{a}}$ (4Q427-432) and, in a few places, fills in material missing from that manuscript (4Q427-432, 4QH ${ }^{\mathrm{a}-\mathrm{e}}$, and 4QpapH $\left.{ }^{\mathrm{f}}\right) .{ }^{9}$ Five were written on animal skins $\left(4 \mathrm{QH}^{\mathrm{a}-\mathrm{e}}\right)$ and one $\left(4 \mathrm{QpapH} \mathrm{H}^{\mathrm{f}}\right)$ on papyrus. The amount of material that is preserved in these badly damaged copies is limited, but there are some places where a cave 4 fragment preserves words and phrases, even partial psalms, that are not found in $1 \mathrm{QH}^{\mathrm{a}}$. They were allotted to John Strugnell, who did extensive work on identifying and analyzing these very fragmentary scrolls; they were eventually published by Eileen Schuller in DJD 29 in 1999. ${ }^{10}$

\section{Relationship between $1 Q H^{\mathrm{a}}, 1 \mathrm{QH} \mathrm{H}^{\mathrm{b}}$, and 4QH ${ }^{\mathrm{a}-\mathrm{f}}$ Manuscript}

The $1 \mathrm{QH}^{\mathrm{a}}$ manuscript is the largest, the most complete, and still the most important copy for working with this collection of poems. ${ }^{11}$ In relationship with

\footnotetext{
${ }^{6}$ There are forty-one lines for columns $\mathrm{i}$ and xviii, according to the new numbering, and forty-two lines starting from column xix (= xii of the Sukenik' edition), which is where there is a change in handwriting; the second copyist took over from that point to the end of the scroll. Further explanation see on the section of reconstruction $1 \mathrm{QH}^{\mathrm{a}}$. See Puech, "Hodayot", 365 and Schuller, "Hodayot", 747.

${ }^{7}$ Schuller and Newsom, The Hodayot, 1.

${ }^{8}$ D. Barthelemy, O. P. And J. T. Milik, Discoveries in the Judean Desert 1 (Oxford: Clarendon Press, 1955), 136-143.

${ }^{9}$ For the overlapped material, see the relationship' section between the $1 \mathrm{QH}^{\mathrm{a}}, 1 \mathrm{QH}^{\mathrm{b}}$, and $4 \mathrm{QH}^{\mathrm{a}-\mathrm{f}}$ manuscript.

${ }^{10}$ Schuller and Newsom, The Hodayot, 1.

${ }^{11}$ The fact that there are eight copies preserved and that $1 \mathrm{QH}^{\mathrm{a}}$ was a large and elegantly crafted scroll
} 
$1 \mathrm{QH}^{\mathrm{b}}$ and $4 \mathrm{QH}^{\mathrm{a}-\mathrm{f}}$, there are some places where those copies can be used to fill in lacuna, both letters and words, in $1 \mathrm{QH}^{\mathrm{a}}$. When these copies are incorporated, columns $4-26$ of $1 \mathrm{QH}^{\mathrm{a}}$ are approximately three-quarters complete. ${ }^{12} 1 \mathrm{QH}^{\mathrm{b}}$, for instance, is corresponding to $1 \mathrm{QH}^{\mathrm{a}} \mathrm{XV} 30$ XVI 1 and XVI 13-14. ${ }^{13}$ In addition, of the approximately 125 fragments in total of $4 \mathrm{QH}^{\mathrm{a}-\mathrm{e}}$ and $4 \mathrm{QpapH}^{\mathrm{f}}$, about forty preserves

indicates that these psalms had importance and authority for the community that wrote them and preserved them in the caves near the Dead Sea.

${ }^{12}$ How are columns 1-3? Unfortunately, very little remains from the first three and what were probably the last two columns of $1 \mathrm{QH}^{\mathrm{a}}$. Column 1, for example, has no fragments that can be placed with any certainty, though it is possible that some of the small unplaced fragments from Scribe A may originate from this first column. Two fragments can be tentatively placed in cols. II and III respectively. It is done through the help of parallel text that has been preserved in other copies. Frag. 16, for instance, has a similar shape and so it may have come from the next column to the right (col. II), at about lines 24-32 (though it is not impossible that it could have come from even one column more to the right, that is col. I). See Emile Puech, "Quelques aspects de la restauration du Rouleau des Hymnes (1QH)." Journal of Jewish Studies 39 (1988), 4. He placed both frgs. 11 and 16 in col. III. The shape of frg. 11 corresponds well to the shape of the bottom right part of col. IV (XVII) and so it may have come from the next column to the right (col. III) at about lines 23-33 towards the middle of the column. See HartmutStegemann and Eileen Schuller, Discoveries in the Judean Desert XL, 1QHODAYOT ${ }^{a}$, trans. Carol Newsom (Oxford: Clarendon Press, 2009), 38, 55, 312. See picture 1 for frg. 11 and picture 2 for frg. 16.

13 Puech states that $1 \mathrm{QH}^{\mathrm{b}}$ overlaps with $1 \mathrm{QH}^{\mathrm{a}}$ (column vii and viii of the edition princeps). See Puech, "Hodayot", 365.

14 All the material in $4 \mathrm{QH}^{\mathrm{a}}$ that overlaps with material in $1 \mathrm{QH}^{\mathrm{a}}$ is from psalms of the 'Hymns of the Community' type. Much of the material is of a somewhat more liturgical nature, that is, psalms containing imperative calls to praise, blessings and first-person plural forms rather than the more usual first-person singular. $4 \mathrm{QH}^{\mathrm{b}}$ seems to have text that overlaps with passage in $1 \mathrm{QH}^{\mathrm{a}} .{ }^{14}$ In addition to filling in some of the lacuna in $1 \mathrm{QH}^{\mathrm{a}},{ }^{15}$ the $4 \mathrm{Q}$ copies are important as we seek to understand how the collection(s) were put together. The manuscripts vary, however, in content and in the ordering of the psalms. ${ }^{16}$ The application of reconstruction methods to the Cave 4 scrolls has yielded valuable new data which suggests that the Cave 4 manuscripts do not contain identical

corresponded with $1 \mathrm{QH}^{\mathrm{a}}$ cols. 1-8. Also, the parallel between $1 \mathrm{QH}^{\mathrm{a}}$ XIII 26 (V 24) with $4 \mathrm{QH}^{\mathrm{b}}$ Frg. $7 \mathrm{Col}$. XXXIV see from the picture 3 and 4 . Four fragments remain from $4 \mathrm{QH}^{\mathrm{c}}$, frg. $1 \mathrm{i}(\mathrm{Col}$. I) are preserved all overlap with columns $13-14$ of $1 \mathrm{QH}^{\mathrm{a}}$. See picture 5 and $6.4 \mathrm{QH}^{\mathrm{d}}$ is a single fragment that overlaps with $1 \mathrm{QH}^{\mathrm{a}}$ XII 15-19. See picture 7 and 8 . $4 \mathrm{QH}^{\mathrm{e}}$ overlapped with a few very small fragments from $1 \mathrm{QH}^{\mathrm{a}}$ 25:34 (frg. 810 ), and the last line of fragment 2 corresponds to $1 \mathrm{QH} 26: 29$ (frg. 7 ii 4). The identifiable fragments of 4QpapH ${ }^{f}$ overlap with 1QH ${ }^{\mathrm{a}}$ IX 13-XVII 36. IX 1-X 5 as 'Creation Hymn' and X 6-XVII 36 as 'Hymns of the Teacher'. It can be established on material grounds that the scroll began with the psalm of $1 \mathrm{QH}^{\mathrm{a}}$ column 9 , the socalled "Creation Hymn," and continued with the Teacher Hymns. Despite of overlapped materials, there is one psalm that is partially preserved in $4 \mathrm{QH}^{\mathrm{a}}$ frg. $8 \mathrm{i} 13$-ii 19 that is not found in any of the preserved columns of $1 \mathrm{QH}^{\mathrm{a}}$ (though it is possible that is was part of cols. 1-3 or cols. 27-28). A few other fragments of significant size in the $4 \mathrm{Q}$ copies have not yet been identified with any text in $1 \mathrm{QH}^{\mathrm{a}}$, and there are many tiny fragments with only a letter or partial letter so that it is impossible to say if they overlap or not. For all these fragments, it is necessary to consult the complete publication of the 4Q manuscripts in DJD XXIX. See E. Chazon, Qumran Cave 4.XX: Poetical and Liturgical Texts, Part 2 ( DJDXXIX; Oxford: Clarendon, 1999), 75; Schuller and Newsom, The Hodayot, 3-4; Eileen M. Schuller, "The Cave 4 Hodayot Manuscripts: Preliminary Description" in Jewish Quarterly Review 85, 1994, 177-194.

${ }^{15}$ Stegemann and Schuller, Discoveries in the Judean Desert XL, 40.

16 The variations between overlapping pieces of compositions within the existing manuscripts from Caves 1 and 4 are many orthographic and do not show any evidence of different recensions. See Schuller, "The Cave 4 Hodayot,", 90. 
collections to $1 \mathrm{QH}^{\mathrm{a}}$. $4 \mathrm{QH}^{\mathrm{b}}$ only appears to be of a similar order and length to $1 \mathrm{QH}^{\mathrm{a}}$. $4 \mathrm{QH}^{\mathrm{a}}$ and $4 \mathrm{QH}^{\mathrm{e}}$, on the other hand, clearly have a different order of psalms than that of $1 \mathrm{QH}^{\mathrm{a}} \cdot{ }^{17}$

\section{THE BRIEF SURVEY}

\section{$1 Q H^{\mathrm{a}}$}

For $1 \mathrm{QH}^{\mathrm{a}}$, this meant presenting first the twelve columns that were joined and relatively well preserved, and the 'the crumpled mass' of seventy fragments arranged basically according to size. ${ }^{18}$ When $1 \mathrm{QH}^{\mathrm{a}}$ came into Sukenik's possession, he described it as "a badly damaged scroll" preserved in two separate parts, "three sheets, each one with four columns, or a total of twelve columns ${ }^{19}$... and a crumpled mass of about 70 detached fragments of various sizes". ${ }^{20} \mathrm{He}$ recognized immediately that two scribes were involved in copying the manuscript, due to the change of hand: the one scribe wrote up until column 11 line 22 (column 19 line 25 in the reconstructed scroll), then another scribe took over in the middle of the

17 To comprehend the order, see picture 9 for comparison of order between $1 \mathrm{QH}^{\mathrm{a}}$ and $4 \mathrm{QH}^{\mathrm{a}}$. To see the comparison between the whole scrolls of hodayot.

${ }^{18}$ Stegemann and Schuller, Discoveries in the Judean Desert XL, 2.

${ }^{19}$ It constitutes plates i-xii in Sukenik. The sheets are about thirteen inches high contain as many as forty lines to a column. See Sukenik, The Dead Sea Scrolls, 1-23.

${ }^{20}$ The latter was difficult to open and was the last to be unrolled. The greater portion of the parchment is dark, to extremely dark, brown and some pieces have become black due to the ravages of time. Menahem Mansoor, The Thanksgiving Hymns, (Grand Rapids, Michigan: Wm. B. Eerdmans, 1961), 4; Sukenik, The Dead Sea Scrolls, 3.

${ }^{21}$ To see the difference, see picture 19.

${ }^{22}$ Lack of understanding of these two ordering and numbering of Hodayot will create confusion when interacting with the sources. line and completed the scroll. ${ }^{21}$ As a result, it can be determined whether a detached fragment, even a very small one, came from the beginning or the end section of the scroll.

\section{The Order and Number of the Columns in $1 \mathbf{Q H}^{\mathrm{a}}$}

Because there are two types of the ordering and numbering of hodayot, it is important to know the differences between them. ${ }^{22}$ The early studies of $1 \mathrm{QH}^{\mathrm{a}}$ used the column and line numbers assigned in the principal edition by Sukenik. ${ }^{23}$ This numbering system, however, has been largely superseded by that of Stegemann and Puech. It was the publication in the late eighties of a paper by Puech which changed the perception of the structure of $1 \mathrm{QH}^{\mathrm{a}}$.Then, this led to a gradual adoption of the Stegemann and Puech' reconstruction and re-numbering of the material.

\section{Sukenik' Order and Number of the Columns. ${ }^{24}$}

In Sukenik's edition, ${ }^{25}$ the twelve columns

\begin{abstract}
${ }^{23}$ Svend Holm-Nielsen, Hodayot Psalms from Qumran (Denmark: Universitetsforlaget I Aarhus, 1960) and Menahem Mansoor, The Thanksgiving Hymns, 33-44.

${ }^{24}$ Stegemann and Schuller, Discoveries in the Judean Desert XL, 13-53.

${ }^{25}$ When Sukenik acquired the Thanksgiving Scroll, it was in two bundles. He described them as follow: the part which was opened first [the first bundle] contains three sheets, each one with four columns, or a total of twelve columns (cols. I-XII). The sheets were not found regularly rolled up into one another, as was the case with the Sons of Light scroll [= 1QM]. Instead, two disconnected sheets were casually rolled together - were probably cols. VVIII and cols. IX-XII -, and into the folds of this roll a third sheet had been forced.. The second part [the second bundle] of the Thanksgiving Scroll was, by the time it reached our hands, a crumpled mass of about seventy detached fragments of leather of assorted sizes.
\end{abstract}


of the first bundle are reproduced from pls. $35-46$, and the fragments of the second bundle on pls. 47-58. Sukenik started with the observation that in the bundle of fragments that he had opened last. ${ }^{26}$ The latter are arranged according to size and according to the scribe who wrote them: pls. 47-51 contain five single columns which were written by one scribe, three columns of which, on pls. 48-50, are connected with another. The rest can be divided into two groups: to one group, pl. 56-57, (cols. XIII-XVII) and frgs. 10-44; ${ }^{27}$ to the other group, pl. 53-55, 58, belong to col. XVIII and frgs. 1-9 and 45-66. ${ }^{28}$ This division corresponds to the paleographic findings from cols. I-XII that came from the first bundle. ${ }^{29}$ greatly facilitated by the changed in handwriting at column XIX (=XII Sukenik's edition), by the direct joining points of numerous fragments and the sheets to be juxtaposed, and by the shapes of the breaks that were repeated at regular spaces in the rolled scroll, all proving that the fragments came from one and the same scroll. Thus, column XVIII of the edition should be considered an erroneous column, and its fragments which certainly do not fit together - should

\footnotetext{
26 Then on pl. 52, there are three fragments that Sukenik put together to form a column (col. XVIII); these were written by another hand. On pls. 53-55, there are the largest fragments (frgs. 1-9) of the second hand; then pls. 56-57 contain the small fragments of the first hand (frgs. 10-44), and on pl. 58 are the remaining smaller fragments of the second hand (frgs. 45-66).

27 Scribe A

${ }^{28}$ Scribe C

29 According to Sukenik, most of these columns were written by a single scribe, but another scribe took over in the middle of col. XIX 29 (XI 26). The identification of this scribe with Scribe $C$ of the fragments was, for Sukenik, indisputable. See picture 19 as an evidence.

${ }^{30}$ Puech, 'Hodayot' in Encyclopedia of the Dead Sea Scrolls, 365.

${ }^{31}$ See picture 19.
}

be separated from it. ${ }^{30}$

\section{The Reconstruction $1 \mathbf{Q H}^{\mathrm{a}}$}

Puech first noted that 1Q35, which had long been recognized as part of the Hodayot, actually contained text which overlapped with that of columns [VII] and [VIII] of $1 \mathrm{QH}^{\mathrm{a}}$ and was therefore a second manuscript, $1 \mathrm{QH}^{\mathrm{b}}$. This identification enabled Puech to reconstruct some missing portions of the text of these columns with proposal to reconstruct the material as belonging to a single scroll. He took note that, as suggested by Sukenik, the pattern of damage and the change of scribal hand could be used as a guide. ${ }^{31}$

Thus, columns [XIII] to [XVII] should precede columns [1] to [XII]. Puech, however, also noted that the identification of columns as one sheet of five columns was inconsistent with the evidence that the other sheets contained only four columns each. He proposed that column [XVII] did not belong to the same sheet as columns [XIII-XVI] but had precede them. ${ }^{32}$ His proposed new order was

$$
\begin{aligned}
& \text { Sheet } 1(\mathrm{I}-\mathrm{IV}): \text { Three lost } \\
& \text { columns + Sukenik [XVII] }{ }^{33}
\end{aligned}
$$

\footnotetext{
${ }^{32}$ See picture 21 and 22.

${ }^{33}$ This method is called as placement made on the basis of the reconstruction. The original beginning of the scroll was badly destroyed by damage that eroded the scroll from within. The consequences of this damage are naturally less pronounced the greater distance from the origin of the damage, moving toward the middle part of the scroll. It is therefore striking that in the reconstructed scroll, cols. IV (XVII + frg. 14), V (XIII + frgs. 15a, 31, 17, $15 \mathrm{~b})$ immediately to the left, the transition from col. $\mathrm{V}$ to col. VI (that is, frgs. $15 \mathrm{~b}+18+22$ ), and likewise the upper part of Sukenik's col. XIV all preserve the upper parts of the column that extend on average about $6 \mathrm{~cm}$ higher compared to the upper edge of the following columns: Sukenik's col. XV in the reconstructed col. VII, and Sukenik's col. XVI in the reconstructed col. VIII. This is even more striking because in the next column, col. IX (I), not
} 
Sheet 2 (V-VIII): Sukenik [XIII$\mathrm{XVI}]$

Sheet 3 (IX-XII): Sukenik [I-IV] Sheet 4 (XIII-XVI):Sukenik [VVIII]

Sheet 5 (XVII-XX):Sukenik [IX$\mathrm{XII}]{ }^{34}$ Puech then turned his attention to the fragments. He disagreed with Sukenik's

Puech then turned his attention to the fragments. He disagreed with Sukenik's assembly of three large fragments as column [XVIII]. Using these and some of the remaining fragments, he reconstructed the final two sheets as follows: Sheet 6 (XXI-XXIV):each col. Contained parts of [XVII] + fragments Sheet

7 (XXV-XXVIII): various fragments ${ }^{35}$ In this paper, the two numbering systems will be distinguished by enclosing Sukenik's numbering within square brackets.

\section{The Benefits of this Reconstruction}

Firstly, the accurate placing of adjacent fragments has enabled more portions of meaningful text to be recovered. Secondly, this method allows the original length of the scroll to be estimated as twenty-seven or twenty-eight columns of forty-one to forty-two lines each. The average length of lines is also known. ${ }^{36}$ Thirdly, it is now possible to investigate the overall structure of the collection, particularly when the data from the Cave 4 manuscripts is also considere $^{37}$ This group contains all of the compositions identified as Teacher Hymns and it strengthens the argument that they represent a distinct group by a single author. ${ }^{38}$

\section{$1 Q H^{\mathrm{b}}$}

Only two fragments remain from this manuscripts (1Q35). ${ }^{39}$ Those fragments, however, do not belong to $1 \mathrm{QH}^{\mathrm{a}} .{ }^{40} \mathrm{On}$ the basis of content, the double transmission of a single psalm in the same scroll would be very surprising; the double transmission of a series of three psalms in one and the same scroll would be inconceivable and without

and they know also the original order of the psalms in this $1 \mathrm{QH}^{\mathrm{a}}$ copy. Most significantly, it is clear that the so-called 'Hymns of the Teacher' come more or less in the middle of the scroll, preceded and followed by 'Hymns of the Community'.

${ }^{38}$ Stegemann and Schuller, Discoveries in the Judean Desert XL, 10. For further discussion see authorship section.

${ }^{39}$ On frg. 1 there are the ends of fourteen lines of writing and overlapped with $1 \mathrm{QH}^{\mathrm{a}} \mathrm{XV} 30 \mathrm{ff}$ (VII $27 \mathrm{ff}$ ). The second fragment, on the other hand, has very narrow lines and only two lines of writings. See Ibid., 45

${ }^{40}$ Milik assigned two fragments that he numbered $1 \mathrm{Q} 35$ to $1 \mathrm{QH}^{\mathrm{a}}$. The writing on these fragments does indeed show a striking affinity with the hand of Scribe A of $1 \mathrm{QH}^{\mathrm{a}}$. 
parallel in similar collections. ${ }^{41}$ Furthermore, in line 5 of 1Q35 1, the shape of lamed is clearly different from that of the lamed in $1 \mathrm{QH}^{\mathrm{a}} .{ }^{42}$ It can also be noted that in $1 \mathrm{Q} 35$ the scribe always joined the middle stroke of the $\sin (1 \mathrm{Q} 35 \mathrm{I} 2,13)$ to the left stroke, whereas Scribe A of 1QH is careful to draw it unjoined between the two side strokes. ${ }^{43}$ However, based on the observation to multiple fragments, it is hard to find consistency of these shapes - lamed and sin -, thus, this argument is unconvincing. ${ }^{44}$ Materially, their shapes are very different from $1 \mathrm{QH}^{\mathrm{a}}$. Thus, they must come from a second scroll of the same collection of psalms (or a scroll of at least part of the collection) that is designated as $1 \mathrm{QH}^{\mathrm{b}} .{ }^{45}$

\section{Q Hodayot Manuscripts}

The six copies from Cave 4 are all fragmentary and badly damaged. ${ }^{46}$ Five are written on leather $\left(4 \mathrm{QH}^{\mathrm{a}-\mathrm{e}}\right)$ and one on papyrus $\left(4 \mathrm{QpapH}^{\mathrm{f}}\right)$.

\begin{tabular}{|l|l|l|}
\hline Manuscript & Fragment(s) Total & Explanation \\
\hline $4 \mathrm{QH}^{\mathrm{a}}$ (4Q427) & $16-22$ & $\begin{array}{l}\text { Written in a semi-cursive hand. } \\
\text { This psalms belong to the category of } \\
\text { theHymns of the Community, }{ }^{47} \text { and } \\
\text { contain a large number of doxological } \\
\text { and liturgical elements with an } \\
\text { emphasis on the union of humans and } \\
\text { angels in praise. }{ }^{48} \text { This may indicate } \\
\text { something about the distinctive nature } \\
\text { of this collection. } \\
\text { One of the distinctive features of } 4 \mathrm{QH}^{\mathrm{a}} \\
\text { is that the psalms appear in assertion of } \\
\text { a new material, text and a different }\end{array}$ \\
\hline
\end{tabular}

\footnotetext{
${ }^{41}$ These fragments contain the remains of three consecutive psalms that appear in the same sequence in $1 \mathrm{QH}^{\mathrm{a}}$ in cols. XV 30-36 (VII 27-33); XV 37-XVI 4 (VII 34-VIII 3); XVI 5-XVII 37 (VIII-IX 37). Also, in the Qumran texts, there is a doublet in the section 1QM XII 7-16 and the lower part of col. XVIII (destroyed)- XIX 8. Doublets can arise from the combination of two originally independent collections that both contain the same passage. See Stegemann and Schuller, Discoveries in the Judean Desert XL, 43.

${ }^{42}$ The paleo-Hebrew lamed in cols. VII 38 (XV 25), IX 28 (I 26), and X 36 (II 34) is formed out of two almost straight lines that meet on the lower left and form a sharp angle. On the other hand, the lamed in Milik's fragment (1Q35 15$)$ has a curved shape on the lower left. Ibid.

${ }^{43}$ Ibid.

44 See Picture 23 for the evidences.

${ }^{45}$ Ibid.

46 The cave 4 materials consist of over one hundred fragments from six manuscripts designated 4Q427-432 (4Q ${ }^{\mathrm{a}-}$ f). most of these are fairly small, persevering just a few letters, with only twenty-five fragments containing ten or more words. The following is a summary of the basic characteristics of the manuscripts. See Schuller, "The Cave 4 Hodayot," 90.

${ }^{47}$ Fragments 9 and 10 (formerly known as frgs. 6 and 7), which overlap with columns XV [VII] and XVI [VIII] of $1 \mathrm{QH}^{\mathrm{a}}$. See Schuller and Newsom, The Hodayot, 10.

48 The use of the plural, series of blessings, and the calendar of the times.

49 The new material from $4 \mathrm{QH}^{\mathrm{a}}$ appears to be a version of the "Self-Glorification Hymn," also attested in the very similar version in $4 \mathrm{Q} 471^{\mathrm{b}}$, and the different but related version in 4Q491C. There are also several small portions of new text from 4Q471 ${ }^{\mathrm{b}}$. See Schuller, "Hodayot," 96-108.
} 
Journal Theology (Kerugma)

E-ISSN: 2622-0962

P-ISSN: 2621-8038

\begin{tabular}{|c|c|c|}
\hline & & order than $1 \mathrm{QH}^{\mathrm{a}}{ }^{50}$ \\
\hline $4 \mathrm{QH}^{\mathrm{b}}(4 \mathrm{Q} 428)$ & $56-69(75 ?)^{51}$ & $\begin{array}{l}\text { Is the earliest copy of } \underline{\text { Hodayot }} \\
\text { Some seventy-five fragments are } \\
\text { preserved, though many are very tiny } \\
\text { and cannot be identified. } \\
\text { This copy was identical with } 1 \mathrm{QH}^{\mathrm{a}} \text { in } \\
\text { the content and order of the psalms. }\end{array}$ \\
\hline $4 \mathrm{QH}^{\mathrm{c}}(4 \mathrm{Q} 429)$ & 6 & $\begin{array}{l}\text { Survives in six fragments giving } \\
\text { remains of eight columns, and the } \\
\text { columns are short (twelve lines) and } \\
\text { narrow; perhaps it was a copy for } \\
\text { personal use. } \\
\text { All the preserved material is from } \\
\text { 'Hymns of the Teacher' collection, and } \\
\text { this manuscript may have contained } \\
\text { only psalms of that type with perhaps } \\
\text { an introductory psalm. } 53\end{array}$ \\
\hline $4 \mathrm{QH}^{\mathrm{d}}(4 \mathrm{Q} 430)$ & 1 & $\begin{array}{l}\text { Is a single fragment that overlaps with } \\
1 \mathrm{QH}^{\mathrm{a}} 12: 15-19 \text {. It is impossible to say } \\
\text { if this one fragment is all that survived } \\
\text { from a complete Hodayot copy or this } \\
\text { was originally a smaller collection. }{ }^{54}\end{array}$ \\
\hline $4 \mathrm{QH}^{\mathrm{e}}(4 \mathrm{Q} 431)$ & 2 & $\begin{array}{l}\text { Is preserved by two fragments. } \\
\text { Two fragments are from a single } \\
\text { psalm, a psalm found also in } 4 \mathrm{QH}^{\mathrm{a}} \text { and } \\
1 \mathrm{QH}^{\mathrm{a}} .{ }^{56}\end{array}$ \\
\hline 4QpapH ${ }^{\mathrm{f}}(4 \mathrm{Q} 432)$ & $22-24$ & Is a badly damaged papyrus scroll of \\
\hline
\end{tabular}

${ }^{50}$ There is clear evidence of this difference in order between $1 \mathrm{QH}^{\mathrm{a}}$ and $4 \mathrm{QH}^{\mathrm{a}}$ in those places where the end of one psalm and the beginning of another is preserved within the same fragment of $4 \mathrm{QH}^{\mathrm{a}}$. That is, that $4 \mathrm{QH}^{\mathrm{a}} \mathrm{had}^{\mathrm{a}}$ different order of psalms is established from the text, quite apart from how individual fragments are arranged and numbered. In fragment 8 of $4 \mathrm{QH}^{\mathrm{a}}$, for instance, this hymn is preceded by a hymn not attested in $1 \mathrm{QH}^{\mathrm{a}}$ whereas in $1 \mathrm{QH}^{\mathrm{a}}$ it is preceded by a hymn which his partially preserved in fragment 3 (formerly known as frgs. 2+11) of $4 \mathrm{QH}^{\mathrm{a}}$. Also, as reconstructed, $4 \mathrm{QH}^{\mathrm{a}}$ is shorter than $1 \mathrm{QH}^{\mathrm{a}}$ and has no preserved text corresponding with the known contents of columns X [II] - XVIII [X] of $1 \mathrm{QH}^{\mathrm{a}}$. See picture for the example. See alsoChazon, Qumran Cave 4 $X X, 78$.

${ }^{51}$ Hughes, Scriptural Allusions and Exegesis in the Hodayot, 10-11. Schuller and Newsom say that there are 75 fragments. See Schuller and Newsom, The Hodayot, 4.

${ }^{52}$ It is most clearly demonstrated by the contents of fragment 8 (formerly known as frg. 3). Fragment 8 II 10-21 corresponds with the composition in $1 \mathrm{QH}^{\mathrm{a}} \mathrm{XX}$ 7-21 [XII 4-18]. 75 fragments to $1 \mathrm{QH}^{\mathrm{a}} \mathrm{x} .35-\mathrm{xxvi} .42$. Puech, 'Hodayot', 366.

${ }^{53}$ Chazon, Qumran Cave $4 X X, 75$.

${ }^{54}$ It is also possible that $4 \mathrm{QH}^{\mathrm{d}}$ and $4 \mathrm{QH}{ }^{\mathrm{e}}$ come from different parts of the same manuscript, but there is no positive evidence to support such a reconstruction. See. See Schuller and Newsom, The Hodayot, 4.

55 The handwriting is very similar and could have come from the same tribe. There are, admittedly, differences between frg. 1 and frg. 2 in the overall appearance of the skin, in the size of letters, and in the distance between the ruled lines. Ibid.

${ }^{56}$ Chazon, Qumran Cave 4XX, 199-202. 


\begin{tabular}{|l|l|l|}
\hline & & $\begin{array}{l}\text { which twenty-nine pieces survive. } \\
\text { There are fragments of the 'Creation } \\
\text { Hymn' and 'Hymns of the Teacher' } 57\end{array}$ \\
\hline
\end{tabular}

\section{The Date of $1 Q H^{A}, 1 Q H^{B}$, and $4 Q H^{A-F}$ Manuscript $^{58}$}

\begin{tabular}{|l|l|}
\hline Manuscripts & Date \\
\hline $1 \mathrm{QH}^{\mathrm{a}}$ & $30-1 \mathrm{BCE}^{59}$ \\
\hline $1 \mathrm{QH}^{\mathrm{b}}$ & $30-1 \mathrm{BCE}^{60}$ \\
\hline $4 \mathrm{QH}^{\mathrm{a}}(4 \mathrm{Q} 427)$ & $\begin{array}{l}75-25 / 1(?) \mathrm{BCE} \text { (late Hasmonean } \\
\text { or early Herodian) }\end{array}$ \\
\hline $4 \mathrm{QH}^{\mathrm{b}}(4 \mathrm{Q} 428)$ & $\begin{array}{l}\text { It is clearly later than the early } \\
\text { Hasmonean semi-formals, but } \\
\text { earlier than the late Hasmonean } \\
\text { and early Herodian rustic semi- } \\
\text { formals. 100-50 BCE }\end{array}$ \\
\hline
\end{tabular}

\footnotetext{
${ }^{57}$ Ibid, 209-212.

${ }^{58}$ Interaction with Puech, 'Hodayot' in Encyclopedia of the Dead Sea Scrolls, 365; Schuller and Newsom, The Hodayot, 1 and Schuller, "The Cave 4 Hodayot," 177-194. Sources: http://www.deadseascrolls.org.il; http://dss.collections.imj.org.il and Florentino Garcia Martinez and Eibert J. C. Tighelaar,The Dead Sea Scrolls Study Edition (Netherlands, Leiden: Brill: 1997). Method: Frank Moore Cross, "The Development of the Jewish Script" in The Bible and Ancient Near East(New York: W. W. Norton \& Company, 1998), 133-188.

${ }^{59}$ Observations: Scribe A: From the left of manuscript Col IV 33 [Suk. Col. XVII]: Khaf, last word,has a similar character with number 4; Col IV 34 [Suk. Col. XVII]: Bet, last word,is number 4 or 5; Col. IV 35 [Suk. Col. XVII]: Lamed, last word,either number 3 or 4 of the formal hand in the Hasmonean and in the Herodian period; for Chet, last word, is probably number 3 although 4 is also possible; Col. IV 36 [Suk. Col. XVII]: Tet, the second last word, is more likely number 4; Col. IX 23 (Suk. Col. I): From the right of manuscript He, on the first word, is number 4; Yod, on the second word, is number 4. See picture 11.Ayin, on the second word, is number 4. $1 \mathrm{QHa}$ : Scribe C: Col. XX 10 (Suk. Col. XII): From the left of manuscript: Bet, last word, is number 4 and Vav, last word, is could be number 3 or 4 . While $1 \mathrm{QH}^{\mathrm{a}-\mathrm{b}}$, with its beautiful calligraphy, largely dates from the beginning of our era or shortly before, the manuscripts from Cave 4 are certainly older. See Puech, 'Hodayot', 366.
}

60 1QHb: Fragment 63: Line 3, the mem is from number 4; Fragment 64: The bet and taw does like number 5. See picture 12 .

${ }^{61}$ The aleph on fragment 409 seems derived from number 2 or 3 ; mem is either 2 or 3 ; and bet is number 3 . See picture 13 


\begin{tabular}{|l|l|}
\hline & ${ }^{\text {Hasmonean }) .}$ \\
\hline $4 \mathrm{QH}^{\mathrm{c}}(4 \mathrm{Q} 429)$ & $\begin{array}{l}\text { Early Part of late Hasmonean - } \\
\text { early Herodian. }\end{array}$ \\
\hline $4 \mathrm{QH}^{\mathrm{d}}(4 \mathrm{Q} 430)$ & Early Herodian. $^{64}$ \\
\hline $4 \mathrm{QH}^{\mathrm{e}}(4 \mathrm{Q} 431)$ & Early Herodian. $^{65}$ \\
\hline $4 \mathrm{QpapH}^{\mathrm{f}}(4 \mathrm{Q} 432)$ & Early Herodian $^{66}$ \\
\hline
\end{tabular}

\section{Authorship}

The authorial unity of the Hymns is challenged because the trend of current research is to distinguish two types of Hymns: the "Hymns of the Teacher," or Thanksgiving Hymns on occasion of a revelation or of a personal release, and the "Hymns of the Community," soteriological confession Hymns by different authors where the "I" has not autobiographical coloring but refers to the members of the Community (Morawe, Jeremias and Kuhn). 67

However, an unmistakable unity of style and vocabulary reveals the single authorship of hodayot. ${ }^{68}$

\section{Summary of Contents}

This collection should be subdivided into two major categories based on the content, vocabulary, and style. In the first group of psalms, the so-called "Hymns of the Teacher," the person, the Teacher of Righteousness, who speaks has an exalted position and often makes the claim to function as a mediator of revelation to others. ${ }^{69}$ In the second category of psalms, the so-called "Hymns of the Community,"

\footnotetext{
${ }^{62}$ Fragment 10 2, first word: waw: 2; bet: 2/3; on the second word: khet is number 2. On line 3, mem, on the last word, is 2 most likely. See picture 14

${ }^{63}$ Fragment 28 , the first word: yod is 3, bet is 4 . The next line, the first word: kaf: 4 . On the 10 line, the first word: peh: 4. See picture 15

64 430: bet 4/5, mem ending: 5, qof: 5 . See picture 16 .

65 431: bet: $4 / 5$, ayin: 5, tsade ending: 4. See picture 17 .

${ }^{66}$ Fragment 3, first word, yod: 5, resh: 5, he: 5; second word: bet, lamed: 5. See picture 18 .

${ }^{67}$ Gunther Morawe, Aufbau und Abgrenzung der Loblieder von Qumranz, TheologischeArbeilen (Berlin: 1961), 16; Gert Jeremias, Der Lehrer der Gerechiigkeil, Studienzur Umwelt des Neuen Testaments (Gottingenz: Vandenhock\& Ruprecht, 1963), 2. Hans W. Kuhn, Enderwartung und gegemvdrtigesHeil: Untersuchungenzu den Gemeindeliedem von Qumran, miteinemAnhanguberEschatologie und Gegenwart in der Verkundigung Jesu. Studienzur Umwelt des Neuen Testaments(Gottingen: Gottingenz: Vandenhock\&Ruprecht, 1964), 4.

${ }^{68}$ Puech argues thata systematic contribution of authorship probably does not do justice to the reality, since the Teacher of Righteousness was no doubt capable of expressing himself to various literary approaches and could vary his vocabulary wherever necessary.His strong personality was certainly not limited to a single type of hymn composition, and could vary between expressing himself in his own name and using his own spiritual experience as a pattern, or composing in a more impersonal manner for his group and for community praise of God. See Puech, 'Hodayot', 367. Sukenik suggested that this author could have been the Teacher of Righteousness himself since certain passages describe how God had given the psalmist a special revelation that he is to share with the members of his community. Through me, you have enlightened the face of the Many (1QH $\left.{ }^{\mathrm{a}} 12: 28\right)$. References to how the psalmist was persecuted and expelled ("they have banished me from my land like a bird from the nest" $1 \mathrm{QH}^{\mathrm{a}}$ 12:9-10) could be referring to the suffering and exile of the Teacher at the hands of the Wicked Priest, as described in other works such as Pesher Habakkuk. See Sukenik, The Dead Sea Scrolls, 3-20.

${ }^{69}$ At least eight psalms of this type (some commentators would add a few more) are grouped together in cols. 1017 , that is, in the middle of the reconstructed $1 \mathrm{QH}^{\mathrm{a}}$ scroll, and it is these same psalms that are found in $4 \mathrm{QH}^{\mathrm{c}}$ and $4 \mathrm{QH}^{\mathrm{f}}$. They have often been read autobiographically as a source of information about the personal religious
} 
the "I" seems to be the corporate voice of the community. The underlying unity of the Hymns is that they are a kind of meditation in which the theological subject is generally dealt with three major areas of focus: God, 70 the salvation of the just, ${ }^{71}$ and the final doom of the godless - beginning with their leader Belial - in an eschatological war. ${ }^{72}$ All these psalms start with a fixed introductory formula, either "I thank you, $\mathrm{O}$ Lord" or "Blessed are you, Lord". It is followed by his reason for offering thanks by recounting what God has done for him. ${ }^{73}$ The main body of each psalm can be quite varied in form and content. Sometimes there is an extended and elaborate development of a specific image or motif. ${ }^{74}$ There is no standard concluding formula; in the biblical psalms of thanksgiving there was often mention in the concluding section of offering sacrifice and fulfilling vows in

experience of the Teacher of Righteousness as well as the early formative years of the community; a minority of scholars have emphasized, however, that much of this language is very formulaic and taken from the biblical psalter, and could be applied more generally to any member of the community. See Puech, 'Hodayot', 365.

${ }^{70}$ God's greatness and perfection is described, along with his justice and kindness, and his forgiveness.

71 The Hymns speak of the persecution and suffering to which the faithful person falls victim and of his hope for the victory of God the Father, and for the punishment of the wicked. Thus, a member belongs to the group of the just or lo the small remnant for whom God is already manifesting his power and mercy, while he will fully manifest his power and justice at the Visitation-Judgment, when all the wicked are destroyed, both Jews and pagans alike (compare the War Scroll). For the just, it will be a time of rejoicing, rewards, delights of Paradise, eternal glory, and peace in the world that has been renewed and purified in the universal conflagration, while Belial will be cast into the burning place of eternal Doom.

72 The conception of eschatology is the same, whether it be in the "Hymns of the Teacher" or in the "Hymns of the Community." The allusions to the total eschatological war, the final and decisive the Temple, but this element is not found in any of these texts.

\section{The Use of Hodayot}

There is very little thing to know about how these psalms were used at Qumran. There are no specific headings or concrete directions for usage on a certain day, month, week, or year like those in other prayer collections. The length of many of the compositions, the absence of set formulas and congregational responses, and the complexity of both the poetic style and the development of ideas have suggested to many scholars that they were intended primarily for personal private meditation and/or instruction. But at least some of these psalms may have been used liturgically in the worship life of the community. ${ }^{75}$

judgment in the heights on earth and in the underworld Abyss, as well as reference to punishment in the infernal Sheol, and to reward with the sons of heaven are found in both categories.

${ }^{73}$ For example, "because you have placed my soul in the bundle of the living" (1QH $\left.{ }^{\mathrm{a}} 10: 22\right)$. See Mansoor, The Thanksgiving Hymns, 3-5.

74 A tree planted in a garden $\left(1 \mathrm{QH}^{\mathrm{a}} 16: 5-27\right)$, a fortified city (1QHa 14:28-32), or woman in labor $\left(1 \mathrm{QH}^{\mathrm{a}} 11: 8-14\right)$. In a few psalms, there are extended descriptions of the eschatological future, with particular emphasis on the destruction of Belial and all the spirits of wickedness $\left(1 \mathrm{QH}^{\mathrm{a}} 11: 26-37\right)$. One long poem toward the end of $1 \mathrm{QH}^{\mathrm{a}}(23: 1-25: 33)$ reflects on the fallen angels and the introduction of sin into the world. See the similarities and dissimilarities for further explanation.

${ }^{75}$ Themes such as the weakness and sinfulness of the human condition and the doxological confession of divine graciousness would be especially appropriate on occasions such as the liturgy for entrance into and renewal of the covenant (1QS 1:18-2:18); perhaps secondarily, these psalms came to be used as part of the daily "entering the covenant of God" (1QS 10:10). There are certain themes in common with the morning blessings in later rabbinic prayer (e.g., knowledge; creation) but the links are general rather than specific. It is tempting to wonder whether these psalms might have been used when the Many 


\section{Related To Other Texts}

\section{Old Testament}

These psalms seem very "biblical-like" because they make extensive use of biblical phraseology and images. Hundreds of allusions have been identified, most of them from Psalms, ${ }^{76}$ Isaiah, and Deuteronomy. Only rarely is there a direct quotation of as much as a whole line; instead, the biblical words and phrases are reworked and reconfigured in an anthological style. The author also expresses, like in the Psalms, his feelings of adoration, praise, gratitude, trust, and faithfulness, while at the same time acknowledging his weakness, fear, guilt, repentance, and sometimes their desire for vengeance for the wickedness of their adversaries and the sinners. ${ }^{77}$

\section{Qumran}

In terms of literary genre, other fragments that should also be included within this literary genre are the fragments of the hymnic compositions such as 1Q36-40, 3Q6, 6Q18, 8Q5, 11Q15-16, the end of 1QRule of the Community ix.26-xi. In addition, the Hymns that are scattered throughout the War Scroll (1QM xii-xix) and the parallels in War Scroll ${ }^{\mathrm{b}}$ (4Q492), and particularly War Scroll ${ }^{\mathrm{a}}$ (4Q49111), which attests to some overlaps with $4 \mathrm{QH}^{\mathrm{a}}$, the Prayer of Michael, and $1 \mathrm{QH}^{\mathrm{a}} \mathrm{xxvi}$. More broadly, they ought to be related to the Songs of the Sage ${ }^{a-b}(4 Q 510-4 Q 511)$, the Songs of the Sabbath Sacrifice ${ }^{\mathrm{a}-\mathrm{b}}$

gathered "to watch together for a third of each night of the year ... to bless together" (1QS 6:8). See Schuller, 'Hodayot', 747-748.

${ }^{76}$ In giving thanks to God the Creator and the one who exercises Divine Providence for his deeds of kindness toward their author(s). Ibid.

${ }^{77}$ Ibid, 367.

${ }^{78}$ Chazon, Qumran Cave 4 XX, 3.
(4Q400-407, as well as 11Q17), the Words of the Luminaries ${ }^{\mathrm{a}-\mathrm{c}}$ (4Q504-506), the Blessing (Berakhot), and the non-canonical Psalms (4Q380-381, 11Q5 ${ }^{\mathrm{a}}$, 4Q88f , 4Q488, 4QPsAp ${ }^{\mathrm{a}}$ among the most notable Qumran compositions). The Hodayot-like texts (4Q433 and 4Q440), ${ }^{78}$ on the other hand, share similarities in form and vocabulary to the Hodayot manuscript $\left(1 \mathrm{QH}^{\mathrm{a}-\mathrm{b}}, 4 \mathrm{QH}^{\mathrm{a}-\mathrm{f}}\right)$ though there is no overlapping text. ${ }^{79}$

\section{Appendix}

\section{Picture 1}

\section{Picture 2}
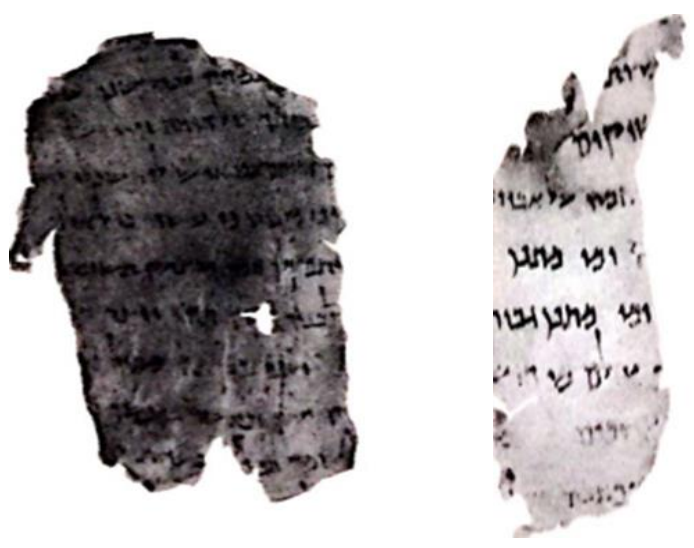

79 For further discussion of the designation 'Hodayot-like', see J. Strugnell and E. Schuller, 'Further Hodayot Manuscript from Qumran?', in AntikesJudentum and frukesChristentum. Festschrift fur HartmutStegemannzum65 Geburtstag, ed. By B. Hollmann, W. Reinbold, A. Steudel (Berlin, New York: de Gruyter, 1998), 51-72 


\section{Picture 3}

1QH ${ }^{\mathrm{a}}$ XIII 26 (V 24)

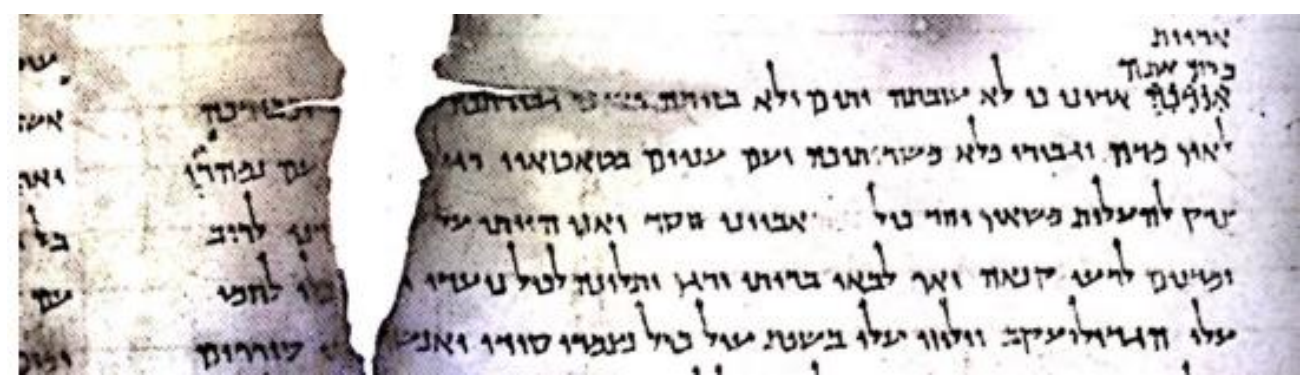

Picture 4

4QH ${ }^{\text {bFrg. }} 7$ Col. XXXIV

now.

Picture 5

4QH'frg. 1 i (Col. I)

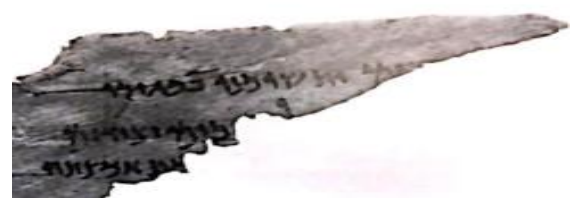

Picture 6

1QH ${ }^{\mathrm{a}}$ XIII 9-11 (V 7-9).

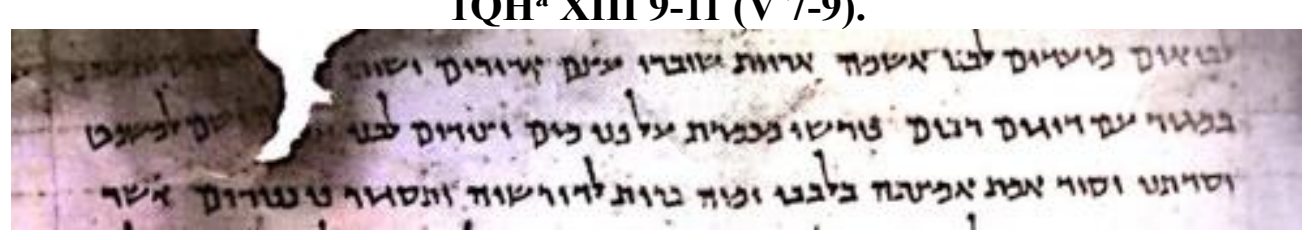

\section{Picture 7}

$4 \mathrm{QH}^{\mathrm{d}}$

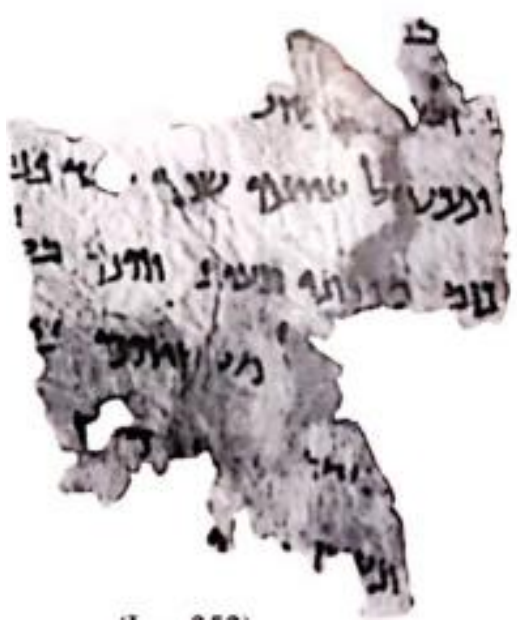




\section{Picture 8}

1QH ${ }^{\text {a }}$ XII 16-17

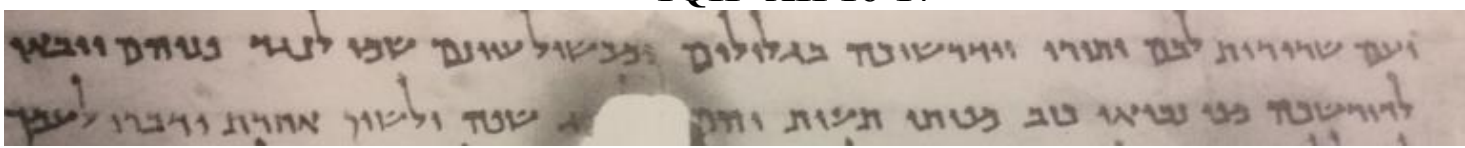

\section{Picture 9}

The order in $4 \mathrm{QH}^{\mathrm{a}}$ and in $1 \mathrm{QH}^{\mathrm{a}}$ can be compared in two instances: ${ }^{2}$

$\begin{array}{ll}4 \mathrm{QH}^{a} & \text { Corresponding text in } 1 \mathrm{QH}^{*} \\ 31-3 & \mathrm{XX} 4-6 \text { (XII 1-3) } \\ 34 & \mathrm{XXV} 34 \text { (frg. 8 10) } \\ 8 \text { i } 6-12 & \text { VII 14-20 (frgs. } 104-10 ; 42 ; 34 ; \text { XV 2-7) } \\ 8 \text { i } 13-\text {-i } 9 & \text { (not present in the preserved sections) } \\ 8 \text { ii } 10-21 & \text { XX 7-21 (XII 4-18) }\end{array}$

\section{Picture 10}

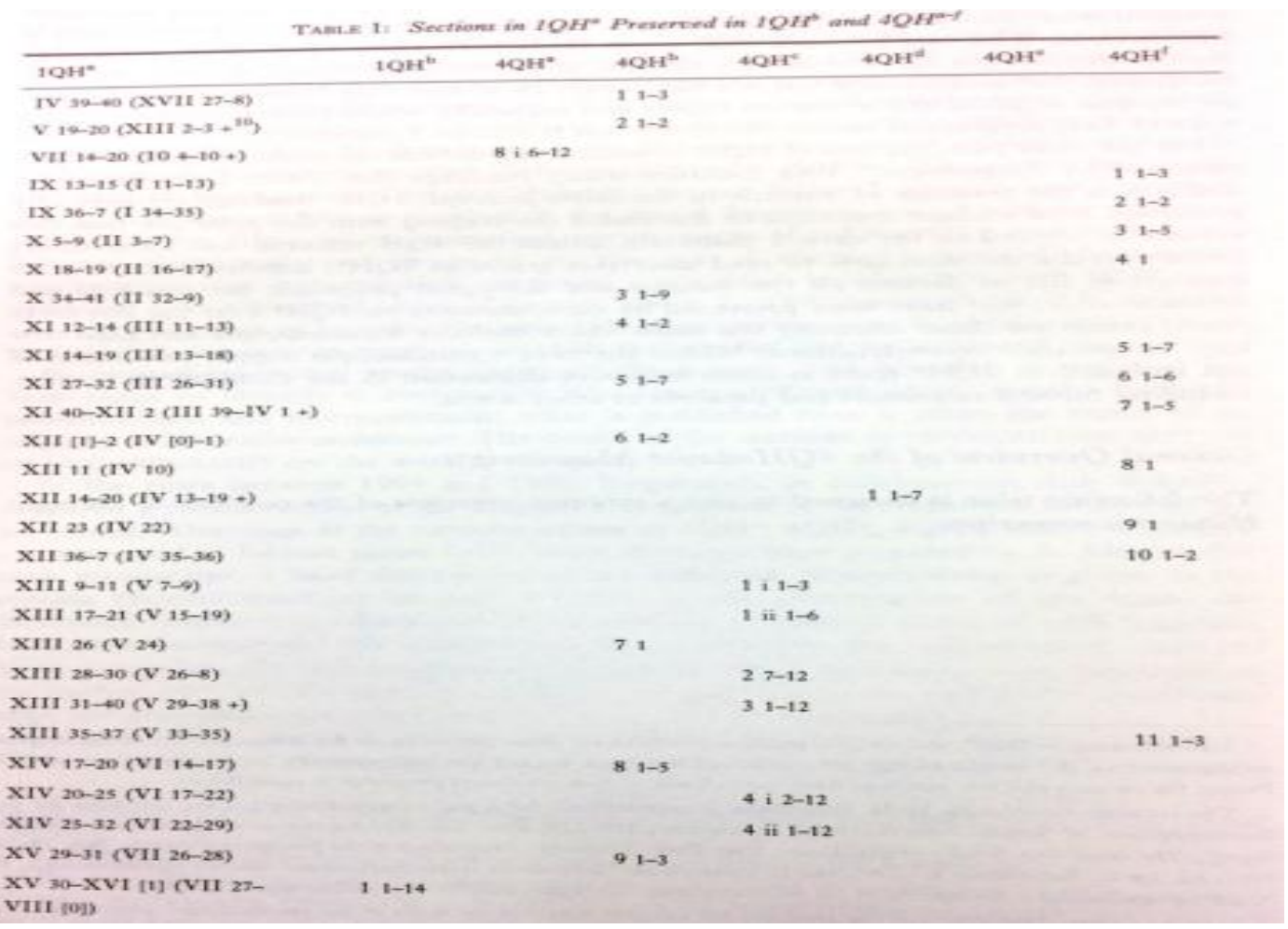




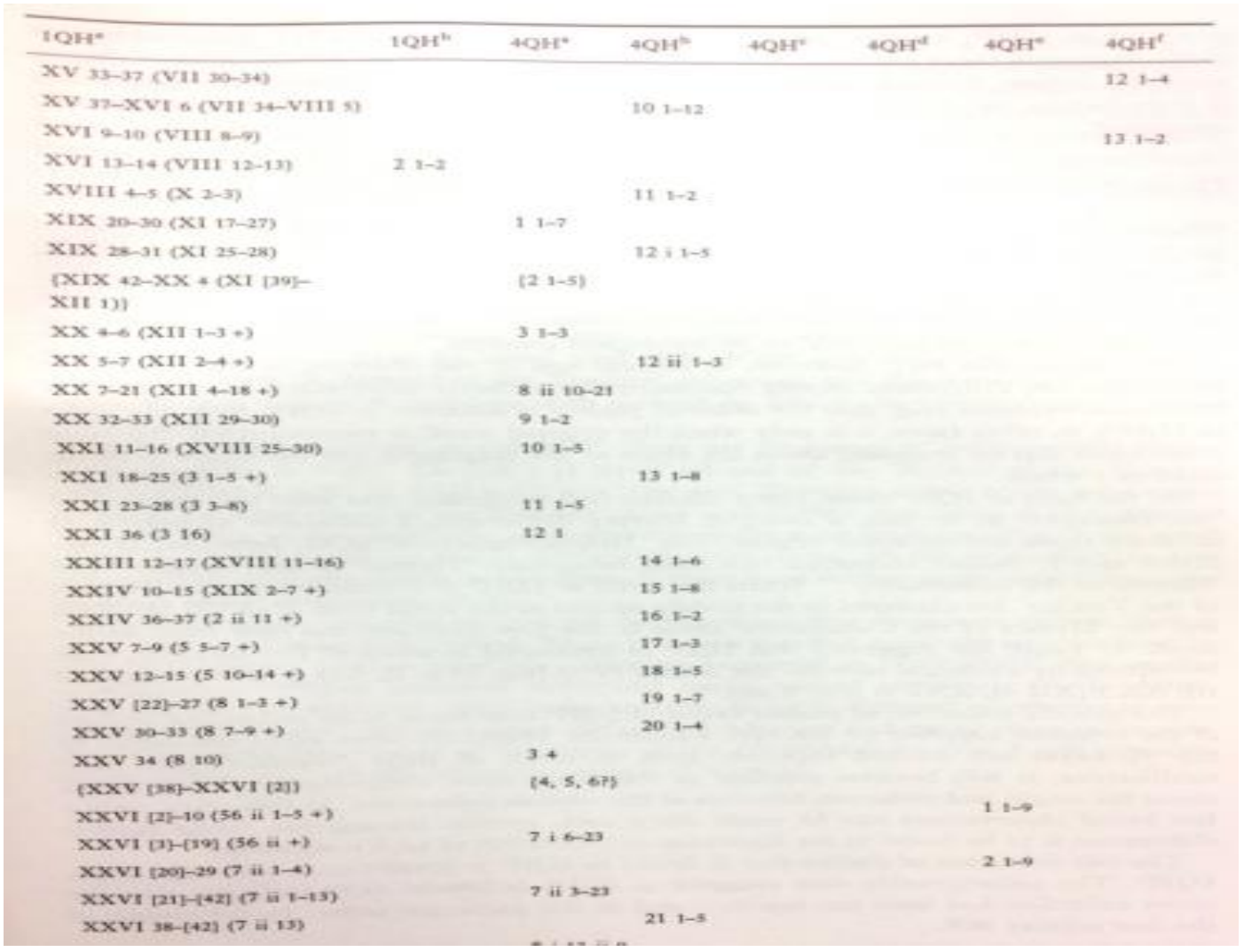

Col. IV 36 [Suk. Col. XVII]: Tet, the second last word.

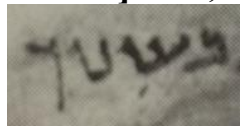

Picture 12

Frg. $63 \quad 64$

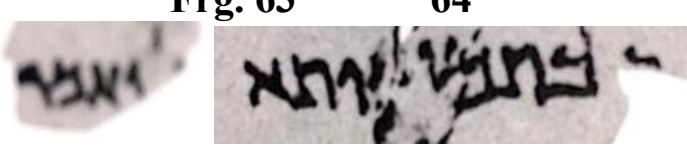

Picture 13

Frg. 409

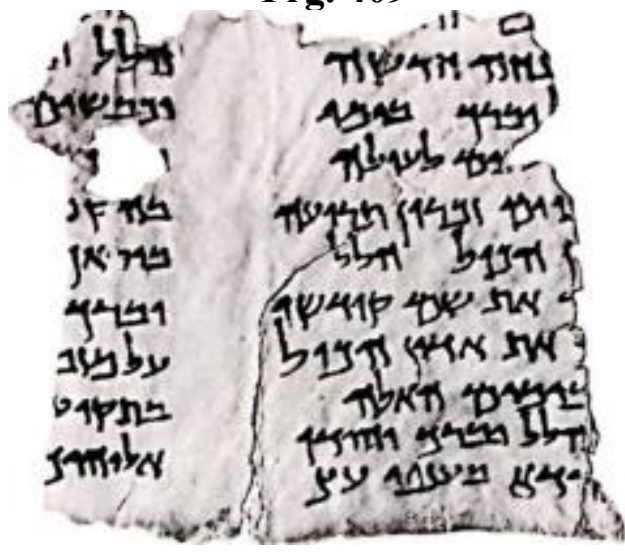


Picture 14

Frg. 102

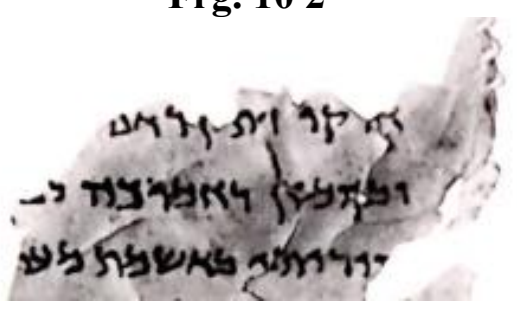

\section{Picture 15}

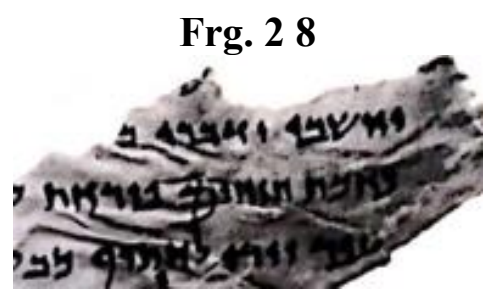

Picture 16

Frg. 430

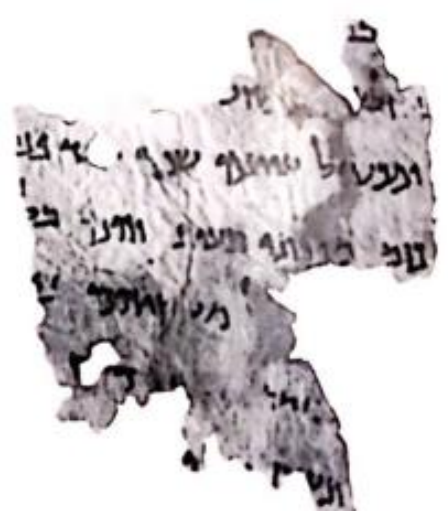

Picture 17

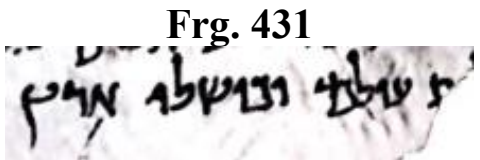

Picture 18

Frg. 3

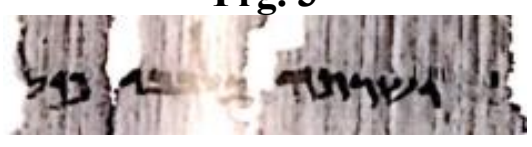



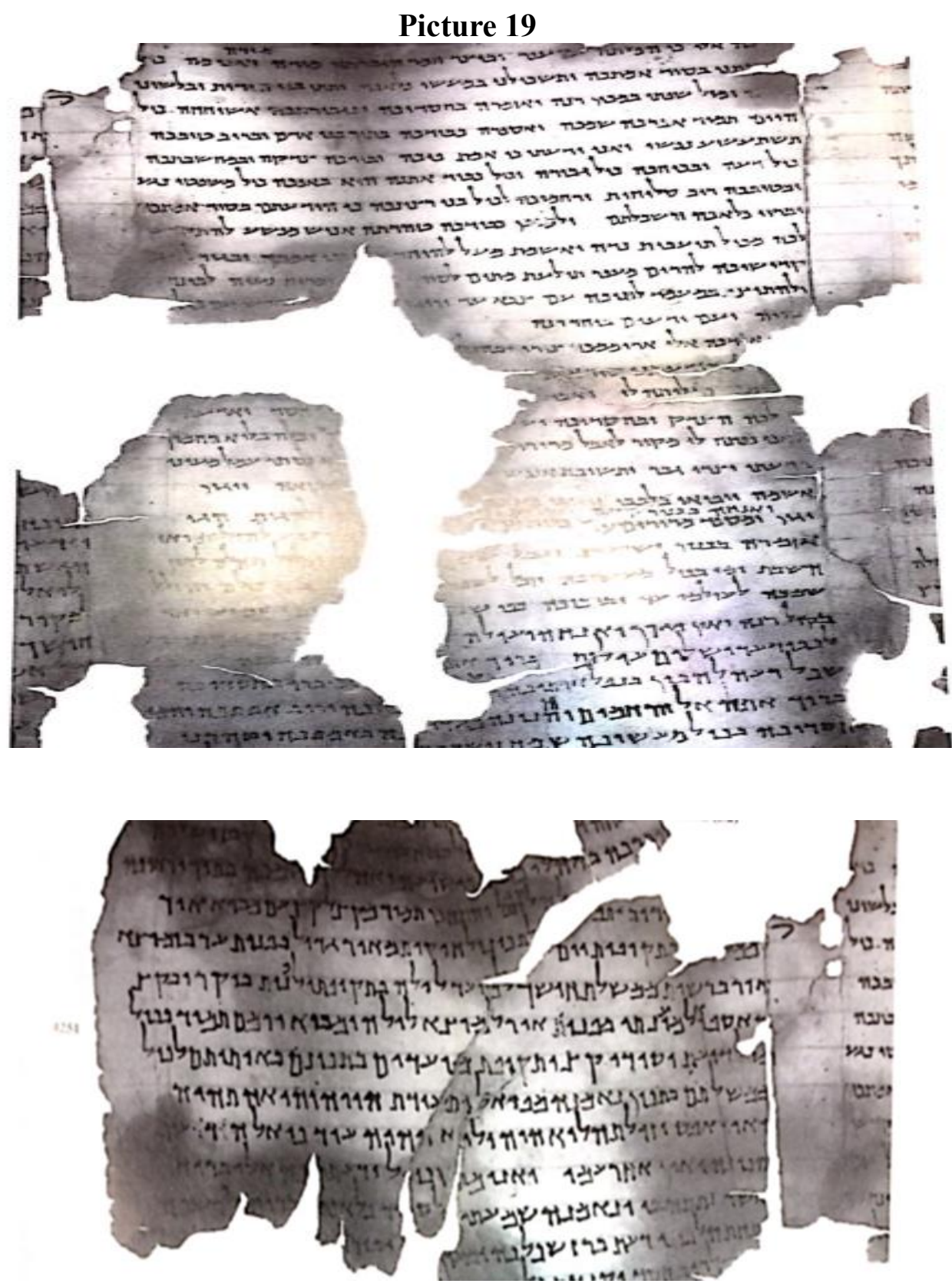

Picture 20 
Jurnal Teologi \& Pelayanan ( Kerusso )

E-ISSN: 2714-9587

P-ISSN: 2407-554X

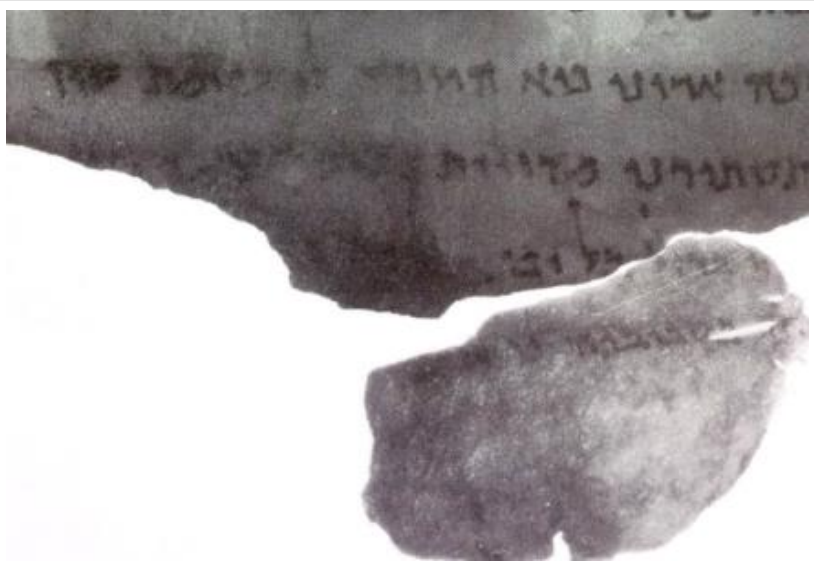

Picture 21

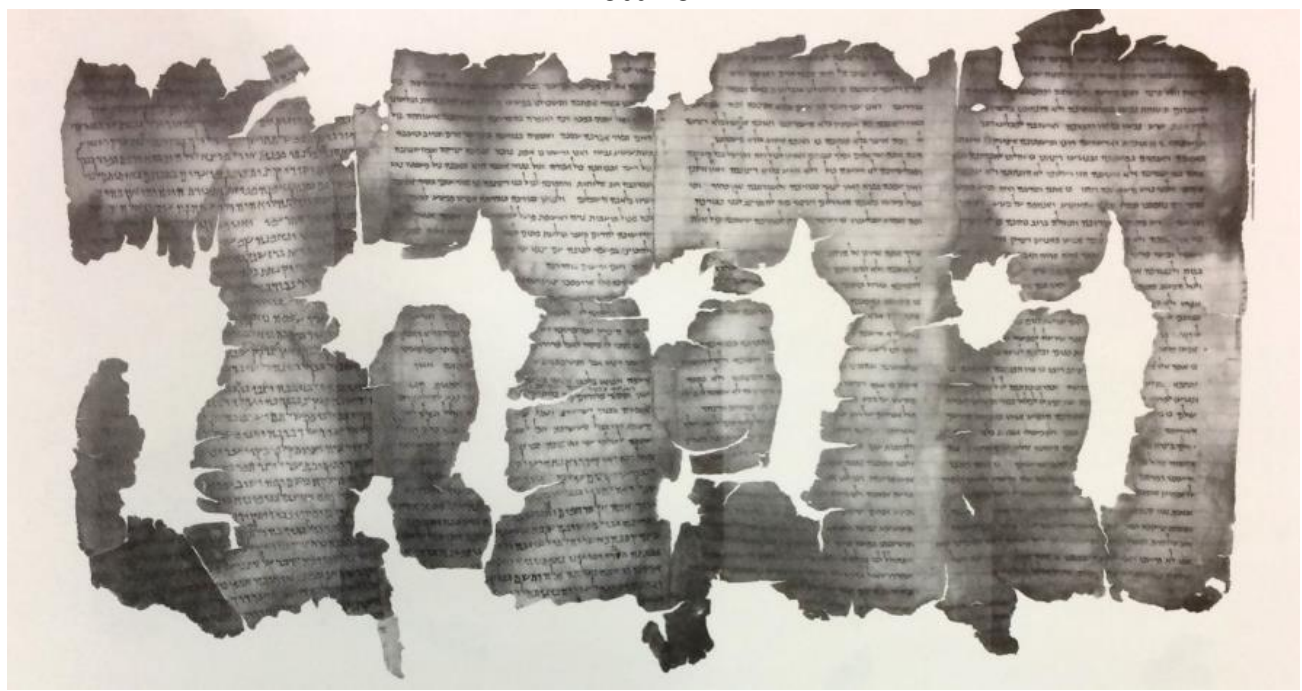

Picture 22

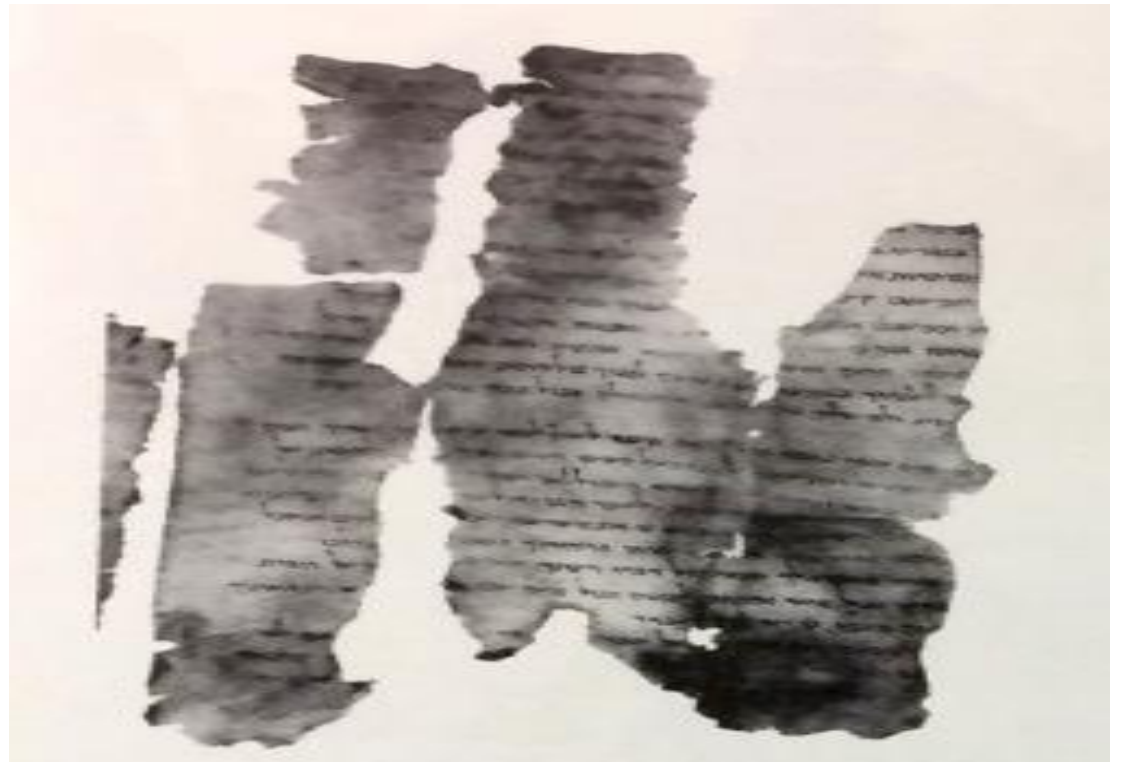



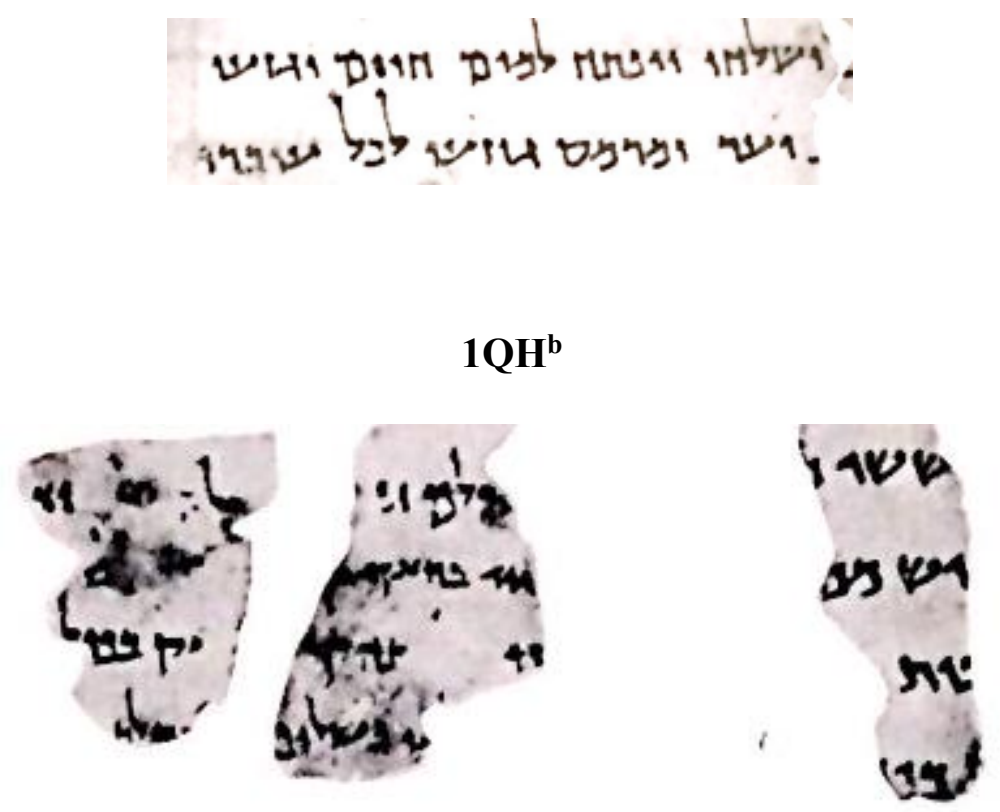

BIBLIOGRAPHY

\section{Primary Source}

[1] Chazon, E. Qumran Cave 4 XX: Poetical and Liturgical Texts, Part 2 DJD XXIX. Oxford: Clarendon, 1999.

[2] Stegemann, Hartmut and Eileen Schuller. Discoveries in the Judean Desert $X L, 1 Q H O D A Y O T^{a}$. translated by Carol Newsom Oxford: Clarendon Press, 2009.

[3] Sukenik, Eleazar. The Dead Sea Scrolls of the Hebrew University. Jerusalem: Magnes Press, Hebrew University, 1955.

[4] O. P. D. Barthelemy, and J. T. Milik. Discoveries in the Judean Desert 1. Oxford: Clarendon Press, 1955.

\section{Secondary Source}

[5] Cross, Frank Moore. "The Development of the Jewish Script" in The Bible and Ancient Near East. New York: W. W. Norton \& Company, 1998.

[6] Holm-Nielsen, Svend. Hodayot Psalms from Qumran. Denmark:

Universitetsforlaget I Aarhus, 1960.

[7] Hughes, Julie A. Scriptural Allusions and Exegesis in the Hodayot. Michigan: Brill, 2006.

[8] Jeremias, Gert. Der Lehrer der Gerechiigkeil, Studienzur Umwelt des Neuen Testaments Gottingenz: Vandenhock\&Ruprecht, 1963.

[9] Kittel, Bonnie Pedrotti. The Hymns of Qumran(Translation and Commentary). Edited by Douglas A. Knight. Ann Arbor, Michigan: Edwards Brothers, Inc., 1981. 
[10] Kuhn, Hans W. Enderwartung und gegemvdrtigesHeil: Untersuchungenzu den Gemeindeliedem von Qumran, miteinemAnhanguberEschatologie und Gegenwart in der Verkundigung Jesu. Studienzur Umwelt des Neuen Testaments.Gottingen: Gottingenz: Vandenhock\&Ruprecht, 1964.

[11] Mansoor, Menahem. The Thanksgiving Hymns. Grand Rapids, Michigan: Wm. B. Eerdmans, 1961.

[12] Martinez, Florentino Garcia and Eibert J. C. Tighelaar. The Dead Sea Scrolls Study Edition.Netherlands, Leiden: Brill: 1997.

[13] Morawe, Gunther. Aufbau und Abgrenzung der Loblieder von Qumranz,Theologische Arbeilen. Berlin: 1961.

[14] Puech, Emile. "Hodayot" in Encyclopedia of the Dead Sea Scrolls. Edited by Lawrence H. Schiffman and James C. VanderKam. Oxford: Oxford University Press, 2000.

[15] "Quelques aspects de la restauration du Rouleau des Hymnes (1QH)." Journal of Jewish Studies 39 (1988).

[16] Schuller, Eileen M., and Carol A. Newsom, The Hodayot (Thanksgiving Psalms): A Study Edition of $1 Q H^{a}$. Atlanta: Society of Biblical Literature, 2012.

[17] "Hodayot" in The Eerdmans of Dictionary Early Judaism. Edited byJohn J. Collins and Daniel C. Harlow. Grand Rapids, Michigan: William B. Eerdmans Publishing Company, 2010.

[18] "The Cave 4 Hodayot Manuscripts: Preliminary Description" in Jewish Quarterly Review 85, 1994.

[19] Stegemann, Hartmut. "Methods for the Reconstruction of Scrolls from Scattered Fragments" in Archeology and History in the Dead Sea Scrolls: The New York University Conference in Memory of YigaelYadin. Edited by L.H. Schiffman. Journal for the Study of Pseudepigrapha: Supplement series 8. Sheffield: Sheffield Academic Press, 1990.
[20] Strugnell, J., and E. Schuller, "Further Hodayot Manuscript from Qumran?', in Antikes Judentum and frukesChristentum. Festschrift fur HartmutStegemannzum65 Geburtstag, ed. By B. Hollmann, W. Reinbold, A. Steudel (BZNW 97; Berlin, New York: de Gruyter, 1998.

\section{Website}

[21] Http://www.deadseascrolls.org.il [22] Http://dss.collections.imj.org.il 